\title{
Cardiac Hormones Target the Ras-MEK 1/2-ERK 1/2 Kinase Cancer Signaling Pathways
}

\author{
David L. Vesely \\ Departments of Internal Medicine, Molecular Pharmacology and Physiology, Cardiac Hormone \\ Center, University of South Florida Health Sciences Center, J. A. Haley Veterans Medical Center-151, \\ 13000 Bruce B. Downs Blvd., Tampa, Florida 33612, USA; E-Mail: david.vesely@va.gov; \\ Tel.: +1-813-972-7624; Fax: +1-813-972-7623
}

Received: 18 February 2011; in revised form: 2 March 2011 / Accepted: 3 March 2011 / Published: 8 March 2011

\begin{abstract}
The heart is a sophisticated endocrine gland synthesizing the atrial natriuretic peptide prohormone which contains four peptide hormones, i.e., atrial natriuretic peptide, vessel dilator, kaliuretic peptide and long-acting natriuretic peptide, which decrease up to $97 \%$ of human pancreatic, breast, colon, prostate, kidney and ovarian carcinomas as well as small-cell and squamous cell lung cancer cells in cell culture. In vivo, these four cardiac hormones eliminate up to $80 \%$ of human pancreatic adenocarcinomas, two-thirds of human breast cancers, and up to $86 \%$ of human small-cell lung cancers growing in athymic mice. Their signaling in cancer cells includes inhibition of up to $95 \%$ of the basal activity of Ras, 98\% inhibition of the phosphorylation of the MEK 1/2 kinases and 97\% inhibition of the activation of basal activity of the ERK $1 / 2$ kinases mediated via the intracellular messenger cyclic GMP. They also completely block the activity of mitogens such as epidermal growth factor's ability to stimulate ERK and Ras. They do not inhibit the activity of ERK in healthy cells such as human fibroblasts. The final step in their anticancer mechanism of action is that they enter the nucleus as demonstrated by immunocytochemical studies to inhibit DNA synthesis within cancer cells.
\end{abstract}

Keywords: Ras; MEK 1/2 kinases; ERK 1/2 kinases; DNA synthesis; cancer; signaling 


\section{Introduction}

The Ras-mitogen-activated protein kinase (MAPK)/extracellular signal-related kinases (ERK) cascade, hereafter referred to as the Ras-MAPK pathway, is a prototypical signal transduction pathway that is aberrantly activated in many neoplasmas including prostate and breast cancers [1,2]. This pathway's activation is associated with a poor prognosis [2]. Structural alteration in the upstream GTPase Ras occurs in $25 \%$ to $30 \%$ of human cancers, which allows them the ability to relay mitogen signals in a ligand-independent manner, thereby obviating the need for ligand activation of growth factor receptors that occurs in normal cells [3,4]. In addition, this pathway contributes to enhanced survival of tumor cells while also facilitating their metastatic spread to distant organs [3]. The integral role of the Ras-MEK-ERK pathway in mediating multiple hallmarks of cancer has suggested that the different kinases in this pathway may be targets for the treatment of cancer [5,6]. Attempts to target Ras by perturbing its interaction with either Son of Sevenless gene (SOS) or growth factor receptorbound 2 (GRB2) have not yielded viable drug development candidates largely because of the inherent difficulties of disrupting protein-protein interactions with drug-like molecules [3]. Several drug discovery programs have been devoted to finding inhibitors of farnesyltransferase as a means to prevent the membrane localization of Ras [3]. Despite the successful identification of several chemical leads that effectively inhibited this prenylation enzyme, tumor cells, however, have proved generally to be impervious to the action of this class of inhibitors [3].

A novel group of anticancer agents, i.e., peptides made by the human heart (Figure 1) have at least a portion of their anticancer signaling via the Ras-MAPK pathway [7-12]. These peptides are termed atrial natriuretic peptides as they are synthesized mainly in the atrium rather than the ventricles of the heart in healthy animals and humans. They are peptides and have sodium excreting properties (natriuresis) in healthy humans [13,14]. These peptides are hormones as they are synthesized in one organ (heart), circulate throughout the body, and have biologic effects of causing a natriuresis in another organ (kidneys). The atrial natriuretic peptide gene synthesizes a prohormone containing four peptide hormones which are involved in blood pressure regulation and maintenance of plasma volume in animals [15-20] and humans [21-23]. These peptide hormones, numbered by their amino acid (a.a.) sequences beginning at the N-terminal end of the atrial natriuretic peptide (ANP) prohormone, consist of the first 30 a.a. of the prohormone, i.e., long-acting natriuretic peptide (LANP), a.a. 31-67 (i.e., vessel dilator), a.a. 79-98 (kaliuretic peptide) and a.a. 99-126 (Figure 1) [24,25].

\section{Cardiac Peptides' Effects on Cancer Cells in Vitro}

The four cardiac hormones from the ANP prohormone decrease up to $97 \%$ of human pancreatic, colon, prostate, breast, ovarian and kidney adenocarcinoma cells [26-31], angiosarcoma of the heart cells [32], melanomas [33], medullary thyroid carcinomas [34], glioblastomas of brain [35], as well as small-cell [36] and squamous cell lung carcinoma cells [37] in cell culture within 24 hours. There was a $97.4 \%, 87 \%, 88 \%$ and $89 \%$ ( $<<0.001$ for each) decrease of human prostate adenocarcinoma cells secondary to vessel dilator, long-acting natriuretic peptide, kaliuretic peptide, and atrial natriuretic peptide, respectively, within 24 hours at their $1 \mathrm{mM}$ concentrations, without any proliferation in the three days following this decrease [28]. 
Figure 1. The atrial natriuretic peptide gene in the heart synthesizes a 126 amino acid (a.a.) prohormone with which proteolytic processing results in the formation of four cardiac hormones. These four cardiac hormones, i.e., (1) long acting natriuretic peptide (LANP) consists of the first 30 amino acids of the 126 a.a. prohormone; (2) vessel dilator (VDL), a.a. 31-67 of the prohormone; (3) kaliuretic peptide (KP), a.a. 79-98 of this prohormone and (4) atrial natriuretic peptide (ANP), consisting of a.a. 99-126 of the 126 a.a. prohormone. Reprinted with permission from [11].

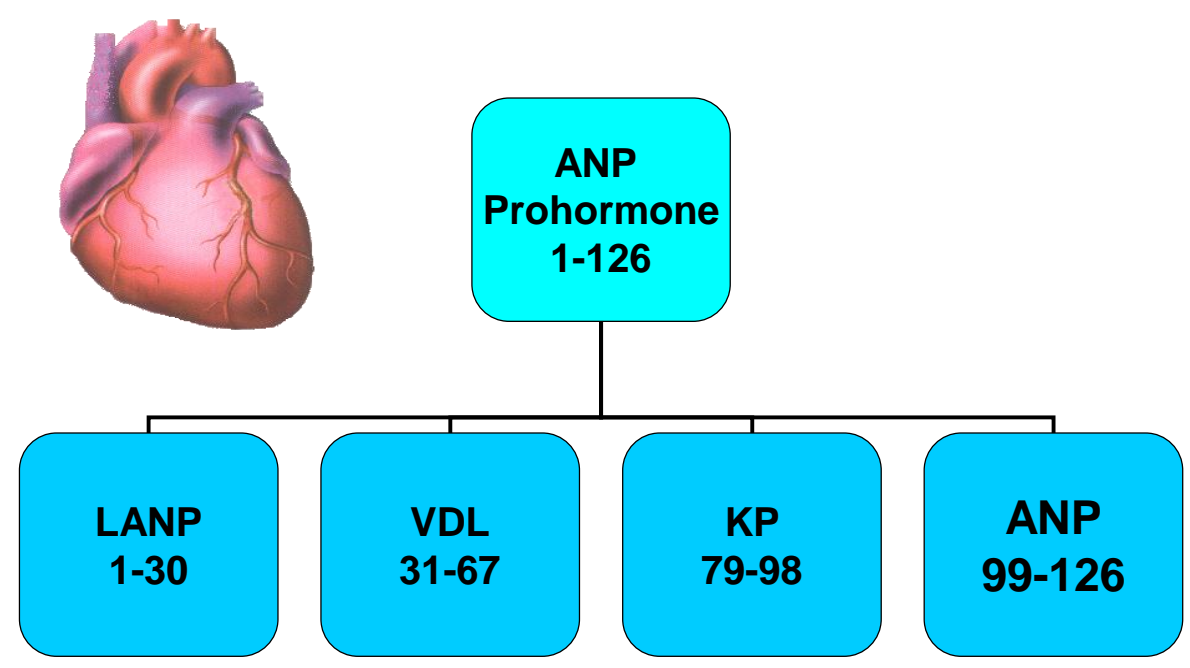

\section{Cardiac Peptides Eliminate Human Cancers Growing in Athymic Mice}

\subsection{Pancreatic Adenocarcinomas}

The five-year survival rate of persons with adenocarcinoma of the pancreas is $1 \%$ with a median survival of only four months [38,39]. Current cancer chemotherapy and surgery prolong survival by a few months, but the mean survival is four months for persons treated with surgery and/or current cancer chemotherapeutic agents [38,39].

When each of these peptides at $3 \mathrm{nM} \mathrm{min}^{-1} \mathrm{~kg}^{-1}$ body weight were infused subcutaneously for 28 days in athymic mice bearing human pancreatic adenocarcinomas, ANP eliminated $80 \%$ the human pancreatic cancers [40]. Vessel dilator, LANP and kaliuretic peptide eliminated the primary pancreatic cancers in $33 \%, 20 \%$, and $14 \%$ of their respective treatment groups [40]. In those animals in which the pancreatic adenocarcinomas were eliminated in the primary site, not a single animal ever had a recurrence in the primary site [40]. One ANP-treated animal developed a metastatic lesion and this lesion was eliminated with treatment with vessel dilator [40]. Even in the treated animals which did not have total elimination of their human pancreatic adenocarcinoma with the osmotic infusion pumps changed weekly, their tumor volume decreased to less than $10 \%$ (and with vessel dilator to less than $2 \%$ ) of that of the untreated animals both during treatment and in a 12-month follow-up period [40].

\subsection{Breast Cancer}

Vessel dilator, LANP, kaliuretic peptide and ANP eliminate 67\%, 50\%, 67\% and 33\% of the human breast adenocarcinomas in athymic mice when infused subcutaneously for 28 days with weekly fresh 
hormones at $3 \mathrm{nM} \mathrm{min}{ }^{-1} \mathrm{~kg}^{-1}$ body weight [41]. There was no recurrence of the breast cancers in the primary site and no metastasis except in the ANP-treated group [41]. The natriuretic peptide receptors $-\mathrm{A}$ and $-\mathrm{C}$ were decreased $50 \%$ and $31 \%$, respectively, in metastatic versus primary ANP-treated breast adenocarcinomas, as a possible reason why less of the breast cancers responded to ANP compared to the other three cardiac hormones as ANP works via these decreased receptors while the other peptide hormones have their own specific receptors [14,41].

\subsection{Small-cell Cancer of the Lung}

LANP, vessel dilator, kaliuretic peptide, ANP and urodilatin (a peptide made in the kidney by differential processing of the ANP prohormone, which consists of ANP plus the four C-terminal amino acids of kaliuretic peptide attached to it) eliminate $86 \%, 71 \%, 57 \%, 43 \%$ ( $p<0.001$ for the cardiac hormones) and $25 \%$ ( $\mathrm{p}<0.05$; urodilatin) of the human small-cell lung carcinomas [42]. The treated small-cell lung carcinomas that were not eliminated grew rapidly, similar to the untreated controls, whose volume was 7-fold larger in one week, 18-fold increased in two weeks, 39-fold increased in three weeks, 63-fold increased in one month and 97-fold increased in volume in six weeks [42]. One vessel dilator treated small-cell lung carcinoma animal developed a large tumor $\left(8,428 \mathrm{~mm}^{3}\right.$ volume $)$ on treatment and this tumor was eliminated utilizing ANP and then LANP sequentially, each for four weeks [42]. Table 1 summarizes the ability of each of the four cardiac hormones to eliminate human breast, pancreatic and small-cell lung cancers growing in athymic mice.

Table 1. Cardiac Hormones Ability to Eliminate Human Cancer Growing in Athymic Mice.

\begin{tabular}{|l|c|c|c|}
\hline & $\begin{array}{l}\text { Breast } \\
\text { Cancer }\end{array}$ & $\begin{array}{l}\text { Pancreatic } \\
\text { Adenocarcinoma }\end{array}$ & $\begin{array}{l}\text { Small-cell } \\
\text { Lung Cancer }\end{array}$ \\
\hline VDL & $67 \%$ & $33 \%$ & $71 \%$ \\
\hline LANP & $50 \%$ & $20 \%$ & $86 \%$ \\
\hline ANP & $33 \%$ & $80 \%$ & $43 \%$ \\
\hline KP & $67 \%$ & $14 \%$ & $57 \%$ \\
\hline
\end{tabular}

The numbers in each column are the percentages of human cancers which are eliminated and never recur in the primary site in athymic mice when treated with each of the cardiac hormones for 28 days at $3 \mathrm{nM} / \mathrm{kg}$ body weight $/$ minute. Abbreviations: $\mathrm{VDL}=$ vessel dilator, $\mathrm{LANP}=$ long acting natriuretic peptide, $\mathrm{ANP}=$ atrial natriuretic peptide, and $\mathrm{KP}=$ kaliuretic peptide.

\section{Cardiac Peptides' Signaling Targets in Cancer Cells}

\subsection{Ras}

Vessel dilator and kaliuretic peptide (each $1 \mu \mathrm{M}$ ) inhibit the activation of Ras GTP from inactive Ras GDP by $95 \%$ ( $<<0.0001$ ) (Figure 2) and 90\% (p < 0.0001), respectively [7]. At $0.01 \mu \mathrm{M}$ of kaliuretic peptide, the maximal inhibition was $95 \%$. The inhibition of Ras lasted for 48 to 72 hours secondary to both peptides [7]. Their ability to inhibit Ras was inhibited by cyclic GMP antibody and cyclic GMP itself inhibited Ras phosphorylation (89\%; $p=0.0015)$ [7]. 
Figure 2. Dose response of vessel dilator on the activation of Ras in human prostate cancer cells at $0.1 \mu \mathrm{mol} / \mathrm{L}$ in time-sequenced experiments at $5,15,30,45$, and 60 minutes. There was a significant $(\mathrm{p}<0.0001)$ inhibition of the activation of Ras at each time point where evaluated by analysis of variance (ANOVA). Ras-GPT (i.e., active Ras) is at $21 \mathrm{kD}$. The relative intensity in these bar graphs is a comparison of three Western blots against the positive control (untreated Ras-GPT) with one typical Western blot illustrated. The illustrated negative control in this graphs is Ras-GDP at $21 \mathrm{kDa}$. Reprinted with permission from [7].
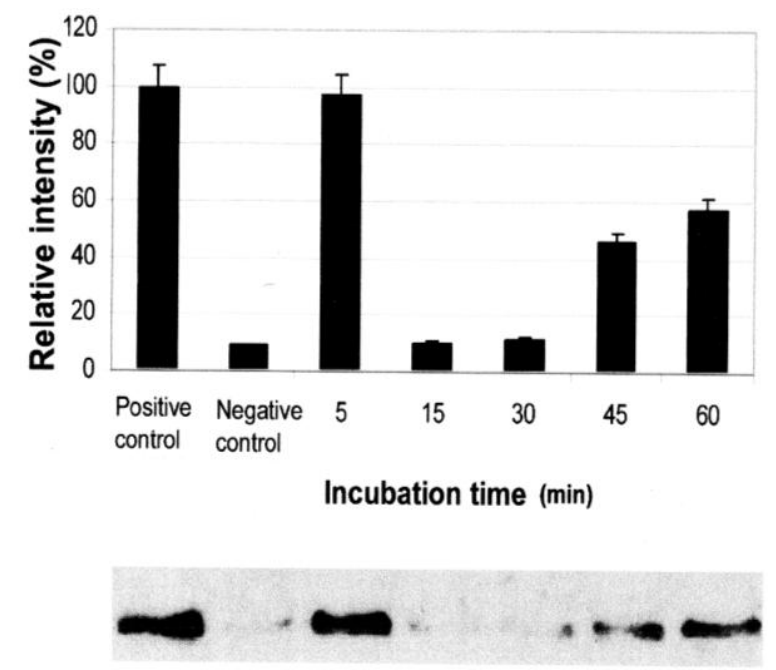

Atrial natriuretic peptide (ANP) and long-acting natriuretic peptide (LANP) reduced the activation of Ras-GTP over a concentration range of $0.01 \mu \mathrm{M}$ to $1 \mu \mathrm{M}$ [8]. ANP and LANP (each $0.1 \mu \mathrm{M}$ ) inhibited the activation of Ras by $90 \%(p<0.0001)$ and $83 \%(p<0.0001)$, respectively [8]. At $0.01 \mu \mathrm{M}$ of LANP, the maximal inhibition was $89 \%$, which occurred within 5 minutes. Both peptide hormones inhibited Ras for three to four hours [8]. Their ability to inhibit Ras was inhibited by cyclic GMP antibody and cyclic GMP itself inhibited Ras phosphorylation (72\%; $p=0.009)$ [8]. Thus, atrial natriuretic peptide, vessel dilator, kaliuretic peptide and long-acting natriuretic peptide inhibit Ras at least partially mediated via cyclic GMP as part of their anticancer mechanism(s) of action [8].

\subsection{MEK 1/2 Kinases}

The prototype member of the MEK kinase family, designated MAP kinase kinase (MKK-1)/or MEK-1, specifically phosphorylates the MAP kinase regulatory threonine and tyrosine residues present in the Thr-Glu-Tyr motif of ERK 1/2 [43,44]. A second MEK family member, i.e., MEK-2, resembles MEK-1 in terms of its substrate specificity but is seven residues longer than MEK-1 with the amino acid sequence of MEK-2 being $81 \%$ identical to MEK-1 [43].

Vessel dilator and kaliuretic peptide decrease the activation of MEK 1/2 over a concentration range of $0.01 \mu \mathrm{M}$ to $10 \mu \mathrm{M}$ [9]. Vessel dilator and kaliuretic peptide (each $10 \mu \mathrm{M}$ ) inhibited the phosphorylation of MEK $1 / 2$ kinase by $98 \%$ ( $p<0.0001$ ) (Figure 3) and $81 \%(\mathrm{p}<0.001)$, respectively [9]. The inhibition of MEK 1/2 lasted for at least two hours, where it was maximal, secondary to both peptides [9]. Their ability to inhibit MEK 1/2 was inhibited by cyclic GMP antibody and cyclic GMP itself inhibited MEK 1/2 phosphorylation, suggesting that cyclic GMP was important for mediating these cardiac hormones' effects [9]. 
Figure 3. Vessel dilator at $10 \mu \mathrm{M}$ inhibits $98 \%$ of the phosphorylation of mitogen-activated protein kinase kinase (MEK 1/2), which was maximal at two hours and significant at $\mathrm{p}<0.00001$ when evaluated by analysis of variance (ANOVA). MEK $1 / 2$ is at $45 \mathrm{kDa}$ while B-actin (loading control) is $42 \mathrm{kDa}$. The relative intensity in the bar graphs is a comparison against untreated MEK 1/2 (100\% intensity). Reprinted with permission from [9].

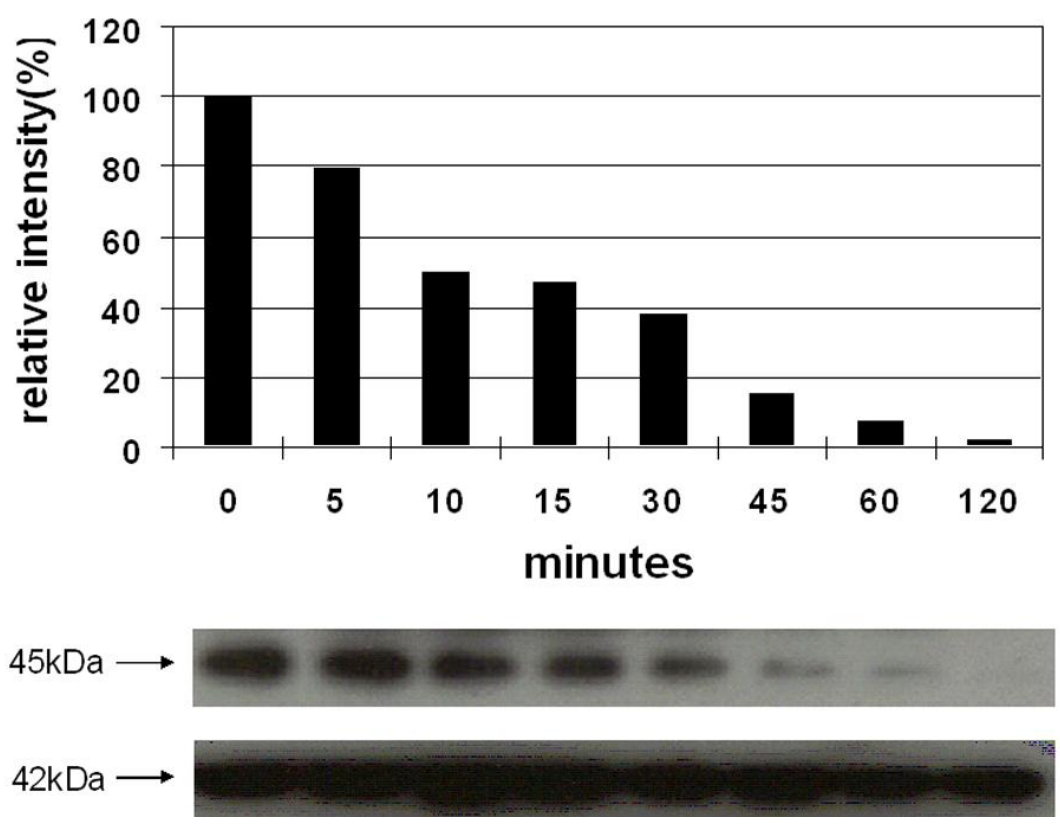

ANP and LANP decreased the activation of MEK 1/2 over a concentration range of $0.01 \mu \mathrm{M}$ to $10 \mu \mathrm{M}$ [10]. LANP and ANP (each $10 \mu \mathrm{M}$ ) inhibited the phosphorylation of MEK 1/2 kinase by $97 \%$ $(\mathrm{p}<0.00001)$ and $88 \%(\mathrm{p}<0.00001)$, respectively [10]. The inhibition of MEK 1/2 was maximal at two hours and ceased by four hours secondary to both peptides [10]. The ability of peptides to inhibit MEK 1/2 was inhibited by cyclic GMP antibody and cyclic GMP itself inhibited MEK 1/2 phosphorylation by 93\% [10]. Thus, ANP, vessel dilator, kaliuretic peptide and LANP each inhibit MEK 1/2 kinase mediated via cyclic GMP as part of their anticancer mechanism(s) of action $[9,10]$.

\subsection{ERK 1/2 Kinases}

Extracellular-signal regulated kinase (ERK) 1/2 is a mitogen activated protein kinase (MAP kinase) important for the growth of cancer(s) $[45,46]$. Growth factors such as epidermal growth factor (EGF), fibroblast growth factor, platelet derived growth factor and vascular endothelial growth factor (VEGF), after binding to their specific receptor tyrosine kinases, work via ERK 1/2 kinase to cause proliferation [45]. EGF, for example, when it binds to its EGF receptor, causes this receptor to autophosphorylate on tyrosine residues and recruits the Grb2-Sos complex to turn on membraneassociated Ras, which then activates the Ras/Raf-Mek 1/2-ERK 1/2 kinase cascade [45]. Of the mitogen-activated protein kinases, ERK 1 and 2, 42 and $44 \mathrm{kDa}$ proteins, can directly translocate to the nucleus and stimulate DNA synthesis and the production of several intermediate early genes such as c-fos and c-myc, which are implicated in causing cells to divide and grow $[45,46]$.

Vessel dilator and kaliuretic peptide decrease the phosphorylation of ERK 1/2 kinases over a concentration range of $0.01 \mu \mathrm{M}$ to $1 \mu \mathrm{M}$ [11]. Vessel dilator and kaliuretic peptide (each $1 \mu \mathrm{M}$ ) inhibit 
the phosphorylation of ERK $1 / 2$ kinase by $96 \%$ and $70 \%$ ( $<0.001$ ), respectively [11]. Both have significant effects within five minutes at a concentration of $0.01 \mu \mathrm{M}$ [11]. The inhibition of ERK $1 / 2$ lasted for at least two hours secondary to both [11]. Their ability to inhibit ERK 1/2 was inhibited by cyclic GMP antibody and cyclic GMP itself inhibited ERK 1/2 phosphorylation [11], suggesting that cyclic GMP is important for mediating their mechanisms of action [11]. Vessel dilator and kaliuretic peptide both inhibit ERK 1/2 kinase mediated via cyclic GMP as a third metabolic target in their anticancer mechanism(s) of action.

ANP and LANP, likewise, decrease the activation of ERK 1/2 kinases over a concentration range of $0.01 \mu \mathrm{M}$ to $10 \mu \mathrm{M}$ [12]. ANP and LANP's maximal inhibition of the phosphorylation of ERK $1 / 2$ kinases were 94\% and 88\% ( $\mathrm{p}<0.0001$ ), respectively [12]. ANP had significant effects within five minutes at a concentration of $10 \mu \mathrm{M}$. The inhibition of ERK 1/2 kinases lasted for at least two hours, where it was maximal, secondary to ANP and LANP. Their ability to inhibit ERK 1/2 was inhibited by cyclic GMP antibody and cyclic GMP itself inhibited ERK 1/2 phosphorylation, suggesting that cyclic GMP mediates their effects of inhibition the phosphorylation of ERK 1/2 kinases [12]. Thus, the cardiac hormones inhibit five metabolic targets, i.e., Ras-GTP, MEK 1/2 kinases and ERK 1/2 kinases as illustrated in Figure 4.

Figure 4. Cardiac hormones inhibit five metabolic targets, i.e., Ras-GTP, MEK 1/2, and ERK 1/2 kinases of the Ras-MEK 1/2-ERK 1/2 kinase cascade by 95-98\%. They are also strong inhibitors (i.e., 91\%) of DNA synthesis within cancer cells. Reprinted with permission from [54].

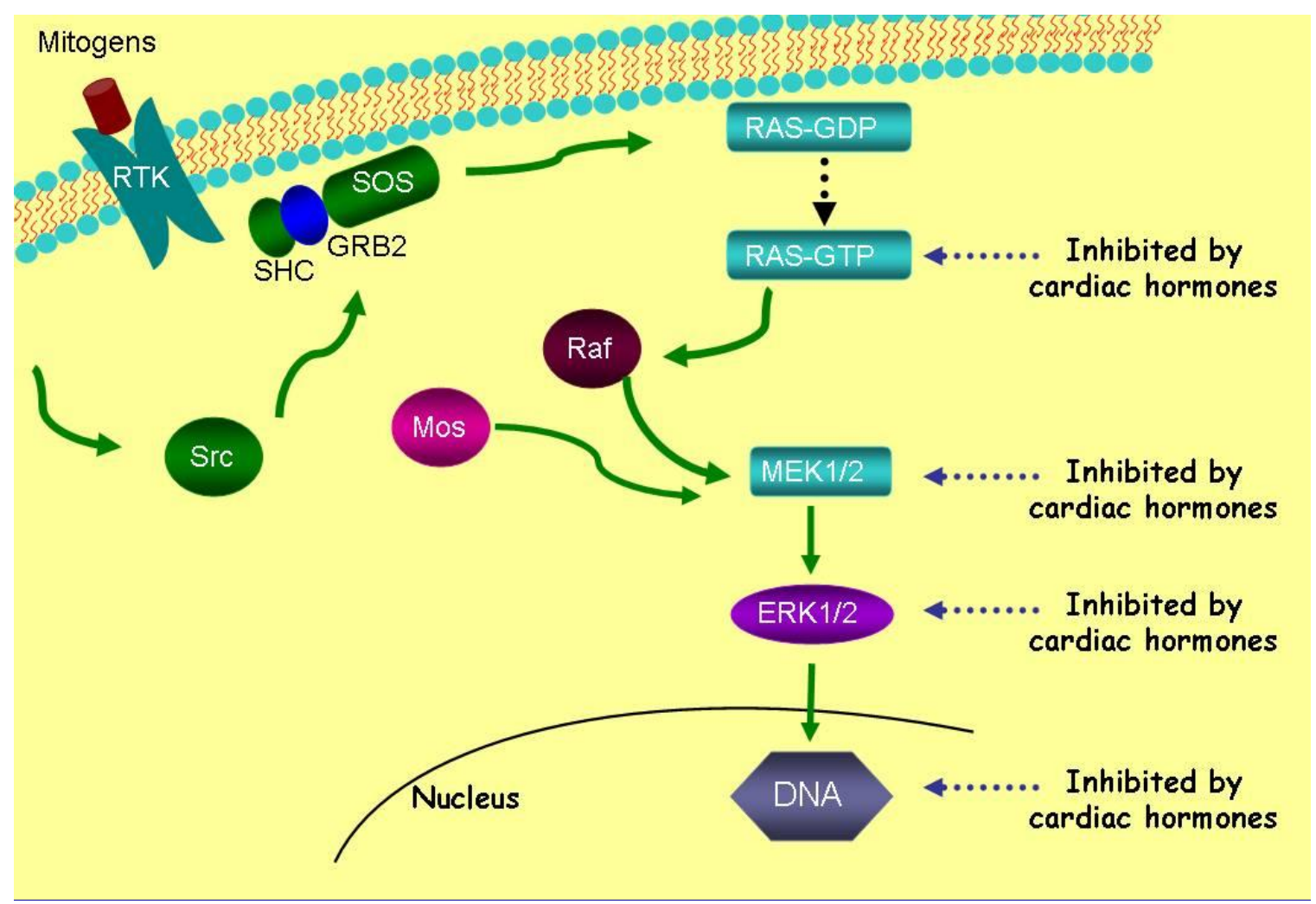




\subsection{Mitogens Stimulation of ERK 1/2 Kinases and Ras Blocked by Cardiac Peptides}

\subsubsection{ERK 1/2 Kinases}

Growth promoting hormones such as epidermal growth factor (EGF) and insulin work as mitogens via ERK 1/2 (mitogen-activated) protein kinase (MAP kinase) to cause growth $[45,46]$.

Insulin $(1 \mu \mathrm{M})$ and EGF $(10 \mathrm{ng} / \mathrm{mL})$ each enhance the phosphorylation of ERK $1 / 2$ by $66 \%$ [47]. This enhanced phosphorylation of ERK $1 / 2$ by EGF and insulin was decreased to $10 \%, 8 \%, 27 \%$ and $13 \%$ above non-stimulated ERK $1 / 2$ by vessel dilator, kaliuretic peptide, LANP and ANP [47].

\subsubsection{Ras}

Insulin's ability to contribute to cancer formation and proliferation is thought to be mediated in part by its ability to convert inactive GDP-Ras to active GTP-Ras [48]. Vessel dilator, LANP, ANP and kaliuretic peptide, each at $1 \mu \mathrm{M}$, inhibit $88 \%, 94 \%, 56 \%$ and $47 \%$, respectively, of insulin's $(1 \mu \mathrm{M})$ activation of Ras [49]. Likewise, epidermal growth factor (EGF) has been shown to directly activate Ras [50-53]. Vessel dilator, LANP, ANP and kaliuretic peptide, each at $1 \mu \mathrm{M}$, inhibit $73 \%, 79 \%, 33 \%$ and $45 \%$, respectively, of $5 \mathrm{ng} / \mathrm{mL}$ EGF stimulation of Ras [54].

\subsection{Cardiac Hormones do not Inhibit ERK 1/2 Kinase in Normal Human Fibroblasts}

Vessel dilator and kaliuretic peptide do not inhibit ERK 1/2 in normal human fibroblasts in a concentration range of $10 \mathrm{pM}$ (physiologic) to $100 \mathrm{nM}(0.1 \mu \mathrm{M})$ as they do in cancer cells [55]. Likewise, the cardiac hormones inhibit proliferation of viable human pancreatic cells but at the same concentrations there is no decrease in proliferation of human prostate, kidney, lung or endothelial cells compared with untreated prostate, kidney, lung or endothelial cells [56].

\subsection{DNA Synthesis}

All four of these cardiac hormones synthesized by the ANP gene localize to the nucleus of human pancreatic adenocarcinomas by immunocytochemical evaluation [57,58], where they can inhibit DNA synthesis.

Vessel dilator, LANP, kaliuretic peptide and ANP, each at $1 \mu \mathrm{M}$ concentration, inhibit DNA synthesis when incubated with pancreatic adenocarcinoma cells for 24 hours by $91 \%, 84 \%, 86 \%$ and $83 \%$, respectively ( $\mathrm{P}<0.001$ for each) [26]. One of the known mediators $[59,60]$ of these peptide hormones' mechanism(s) of action, i.e., cyclic GMP, inhibited DNA synthesis in these adenocarcinoma cells by $51 \%$ [26]. Dose-response curves revealed that 8-bromo-cyclic GMP, the cell permeable analog of cyclic GMP, decreased DNA synthesis in these cancer cells $46 \%, 42 \%, 39 \%$, and $34 \%$ (all $\mathrm{P}<0.05$ ) at concentrations of $3 \mathrm{mM}, 1 \mathrm{mM}, 100 \mu \mathrm{M}$, and $1 \mu \mathrm{M}$, respectively [26]. Even at $1 \mathrm{nM}$ (i.e., $10^{-9} \mathrm{M}$ ) of 8-bromo-cyclic GMP there was a $25 \%$ decrease in DNA synthesis in the adenocarcinoma cells $(\mathrm{P}<0.05)$ [26]. At $100 \mathrm{pM}$ of 8-bromo cyclic GMP, its effects on DNA synthesis in these adenocarcinoma cells became not significant (14\% decrease) [26]. 


\section{Conclusions}

Vessel dilator, LANP, kaliuretic peptide and ANP inhibit DNA synthesis 80-91\% in all human cancer cell lines [26-37]. Thus, after inhibiting ERK 1/2, DNA synthesis (a further or final step in the Ras-MEK 1/2-ERK 1/2 kinase pathway) is inhibited within the nucleus (Figure 4). These peptide hormones' ability to inhibit DNA synthesis is specifically mediated by the intracellular mediator cyclic GMP as when a cyclic GMP antibody is incubated with the cardiac hormones they are unable to inhibit DNA synthesis [29]. Thus, with respect to signaling in cancer cells, after inhibiting the Ras-MEK 1/2ERK 1/2 kinase cascade (Figure 4), the cardiac peptides can inhibit DNA synthesis secondarily by ERK 1/2 kinases' mediated decrease in DNA synthesis or possibly directly since they have been shown by immunocytochemical studies [57,58] to enter the nucleus where they can inhibit DNA synthesis.

\section{Acknowledgement}

This work was supported in part by a United States Department of Veterans Affairs Merit Review Award (D.L. Vesely). I thank Karen Murphy for excellent secretarial assistance.

\section{References}

1. Scholl, F.A.; Dumesic, P.A.; Khayari, P.A. Recurrence of active MEK 1 expressions in vivo. Cancer Lett. 2005, 230, 1-5.

2. McCubrey, J.A.; Steelman, L.S.; Chappell, W.H.; Abrams, S.L.; Wong, E.W.T.; Chang, F.; Lehmann, B.; Terrian, D.M.; Milella, M.; Tafuri, A.; Stivala, F.; Libra, M.; Basecke, J.; Evangeliste, C.; Martelli, A.M.; Franklin, R.A. Roles of the Raf/MEK/ERK pathway in cell growth, malignant transformation and drug resistance. Biochim. Biophys. Acta 2007, 1773, 1263-1284.

3. Sebolt-Leopold, J.S. Advances in the development of cancer therapeutics directed against the Ras mitogen-activated protein kinase pathway. Clin. Can. Res. 2008, 14, 3651-3656.

4. McCubrey, J.A.; Milella, M.; Tafuri, A.; Martelli, A.M.; Lunghi, P.; Bonati, A.; Cervello, M.; Lee, J.T.; Steelman, L.S. Targeting the Raf/MEK/ERK pathway with small-molecule inhibitors. Curr. Opin. Investig. Drugs 2008, 9, 614-630.

5. Sebolt-Leopold, J.S.; Herrera, R. Targeting the mitogen-activated protein kinase cascade to treat cancer. Nat. Rev. Cancer 2004, 4, 937-947.

6. Roberts, P.J.; Der, C.J. Targeting the RAF-MEK-ERK mitogen-activated protein kinase cascade for the treatment of cancer. Oncogene 2007, 26, 3291-3310.

7. Sun, Y.; Eichelbaum, E.J.; Skelton, W.P. IV; Lenz, A.; Regales, N.; Wang, H.; Vesely, D.L. Vessel dilator and kaliuretic peptide inhibit Ras in human prostate cancer cells. Anticancer Res. 2009, 29, 971-975.

8. Sun, Y.; Eichelbaum, E.J.; Lenz, A.; Skelton, W.P. IV; Wang, H.; Vesely, D.L. Atrial natriuretic peptide and long-acting natriuretic peptide inhibit Ras in human prostate cancer cells. Anticancer Res. 2009, 29, 1889-1893. 
9. Sun, Y.; Eichelbaum, E.J.; Wang, H.; Vesely, D.L. Vessel dilator and kaliuretic peptide inhibit MEK 1/2 activation in human prostate cancer cells. Anticancer Res. 2007, 27, 1387-1392.

10. Sun, Y.; Eichelbaum, E.J.; Wang, H.; Vesely, D.L. Atrial natriuretic peptide and long acting natriuretic peptide inhibit MEK 1/2 activation in human prostate cancer cells. Anticancer Res. 2007, 27, 3813-3818.

11. Sun, Y.; Eichelbaum, E.J.; Wang, H.; Vesely, D.L. Vessel dilator and kaliuretic peptide Inhibit activation of ERK 1/2 in human prostate cancer cells. Anticancer Res. 2006, 26, 32173222.

12. Sun, Y.; Eichelbaum, E.J.; Wang, H.; Vesely, D.L. Atrial natriuretic peptide and long acting natriuretic peptide inhibit ERK 1/2 in prostate cancer cells. Anticancer Res. 2006, 26, 4143-4148.

13. Brenner, B.M.; Ballermann, B.J.; Gunning, M.E.; Ziedel, M.L. Diverse biological actions of atrial natriuretic peptide. Physiol. Rev. 1990, 70, 665-699.

14. Vesely, D.L. Natriuretic Hormones. In The Kidney: Physiology and Pathophysiology, 4th ed.; Alpern, R.J., Herbert, S.C., Eds.; Elsevier/Academic Press: San Diego, CA, USA, 2007; pp. 947-977.

15. Martin, D.R.; Pevahouse, J.B.; Trigg, D.J.; Vesely, D.L.; Buerkert, J.E. Three peptides from the ANF prohormone $\mathrm{NH}_{2}$-terminus are natriuretic and/or kaliuretic. Am. J. Physiol. 1990, 258, F1401-F1408.

16. Gunning, M.E.; Brady H.R.; Otuechere, G.; Brenner, B.M.; Ziedel, M.L. Atrial natriuretic peptide (31-67] inhibits Na transport in rabbit inner medullary collecting duct cells: Role of prostaglandin $\mathrm{E}_{2}$. J. Clin. Invest. 1992, 89, 1411-1417.

17. Benjamin, B.A.; Peterson, T.V. Effects of proANF (31-67) on sodium excretion in conscious monkeys. Am. J. Physiol. 1995, 269, R1351-R1355.

18. Zeidel, M.L. Regulation of collecting duct $\mathrm{Na}^{+}$reabsorption by ANP 31-67. Clin. Exp. Pharmacol. Physiol. 1995, 22, 121-124.

19. Villarreal, D.; Reams, G.P.; Taraben, A.; Freeman, R.H. Hemodynamic and renal effects of proANF 31-67 in hypertensive rats. Proc. Soc. Exp. Biol. Med. 1999, 221, 166-170.

20. Dietz, J.R.; Scott, D.Y.; Landon, C.S.; Nazian, S.J. Evidence supporting a physiological role for proANP (1-30) in the regulation of renal excretion. Am. J. Physiol. 2001, 280, R1510-R1517.

21. Vesely, D.L.; Douglass, M.A.; Dietz, J.R.; Gower, W.R., Jr.; McCormick, M.T.; Rodriguez-Paz, G.; Schocken, D.D. Three peptides from the atrial natriuretic factor prohormone amino terminus lower blood pressure and produce diuresis, natriuresis and/or kaliuresis in humans. Circulation 1994, 90, 1129-1140.

22. Vesely, D.L.; Douglass, M.A.; Dietz, J.R.; Gower, W.R., Jr.; McCormick, M.R.; Rodriguez-Paz, G; Schocken, D.D. Negative feedback of atrial natriuretic peptides. J. Clin. Endocrinol. Metab. 1994, 78, 1128-1134.

23. Vesely, D.L.; Dietz, J.R.; Parks, J.R.; Baig, M.; McCormick, M.R.; Cintron, G.; Schocken, DD. Vessel dilator enhances sodium and water excretion and has beneficial hemodynamic effects in persons with congestive heart failure. Circulation 1998, 98, 323-329.

24. Vesely, D.L. Atrial Natriuretic Hormones; Prentice Hall: Englewood Cliffs, NJ, USA, 1992, $1-256$.

25. Vesely, D.L. Atrial natriuretic peptide prohormone gene expression: Hormones and diseases that upregulate its expression. IUBMB Life 2002, 53, 153-159. 
26. Vesely, B.A.; McAfee, Q.; Gower, W.R., Jr.; Vesely, D.L. Four peptides decrease the number of human pancreatic adenocarcinoma cells. Eur. J. Clin. Invest. 2003, 33, 998-1005.

27. Vesely, B.A.; Song, S.; Sanchez-Ramos, J.; Fitz, S.R.; Solivan, S.R.; Gower, W.R., Jr.; Vesely, D.L. Four peptide hormones decrease the number of human breast adenocarcinoma cells. Eur. $J$. Clin. Invest. 2005, 35, 60-69.

28. Vesely, B.A.; Alli, A.A.; Song, S.; Gower, W.R., Jr.; Sanchez-Ramos, J.; Vesely, D.L. Four peptide hormones specific decrease (up to 97\%) of human prostate carcinoma cells. Eur. J. Clin. Invest. 2005, 35, 700-710.

29. Gower, W.R., Jr.; Vesely, B.A.; Alli, A.A.; Vesely, D.L. Four peptides decrease human colon adenocarcinoma cell number and DNA synthesis via guanosine 3',5'-cyclic monophosphate. Int. J. Gastrointestinal Cancer 2006, 36, 77-87.

30. Vesely, B.A.; Eichelbaum, E.J.; Alli, A.A.; Sun, Y.; Gower, W.R., Jr.; Vesely, D.L. Urodilatin and four cardiac hormones decrease human renal carcinoma cell number. Eur. J. Clin. Invest. 2006, 36, 810-819.

31. Vesely, B.A.; Eichelbaum, E.J.; Alli, A.A.; Sun, Y.; Gower, W.R., Jr.; Vesely, D.L. Four cardiac hormones cause cell death in $81 \%$ of human ovarian adenocarcinoma cells. Cancer Therapy 2007, 5, 97-104.

32. Vesely, B.A.; Alli A.; Song, S.; Sanchez-Ramos, J.; Fitz, S.R.; Gower, W.R., Jr.; Vesely, D.L. Primary malignant tumors of the heart: Four cardiovascular hormones decrease the number and DNA synthesis of human angiosarcoma cells. Cardiology 2006, 105, 226-233.

33. Vesely, B.A.; Eichelbaum, E.J.; Alli, A.A.; Sun, Y.; Gower, W.R., Jr.; Vesely, D.L. Four cardiac hormones cause cell death of melanoma cells and inhibit their DNA synthesis. Am. J. Med. Sci. 2007, 334, 342-349.

34. Eichelbaum, E.J.; Vesely, B.A.; Alli, A.A.; Sun, Y.; Gower, W.R., Jr.; Vesely, D.L. Four cardiac hormones decrease up to $82 \%$ of human medullary thyroid carcinoma cells within 24 hours. Endocrine 2006, 30, 325-332.

35. Vesely, B.A.; Eichelbaum, E.J.; Alli, A.A.; Sun, Y.; Gower, W.R., Jr.; Vesely, D.L. Four cardiac hormones eliminate 4-fold more human glioblastoma cells than green mamba snake peptide. Cancer Lett. 2007, 254, 94-101.

36. Vesely, B.A.; Song, S.; Sanchez-Ramos, J.; Fitz, S.R.; Gower, W.R., Jr.; Vesely, D.L. Five cardiac hormones decrease the number of human small-cell cancer cells. Eur. J. Clin. Invest. 2005, 35, 388-398.

37. Vesely, B.A.; Fitz, S.R.; Gower, W.R., Jr.; Vesely, D.L. Vessel dilator: Most potent of the atrial natriuretic peptides in decreasing the number and DNA synthesis of squamous lung cancer cells. Cancer Lett. 2006, 233, 226-231.

38. Pitchumoni CS. Pancreatic Disease. In Internal Medicine; Stein, J.H., Ed.; Mosby: St Louis, MO, USA, 1998; 2233-2247.

39. Wolff, R.A.; Abbruzzese, J.L.; Evans, D.B. Neoplasms of the exocrine pancreas. In Cancer Medicine; Holland, J.F., Frei, E., III, Eds.; BC Decker Inc: London, UK, 2000; 1436-1464.

40. Vesely, D.L.; Eichelbaum, E.J.; Sun, Y.; Alli, A.A.; Vesely, B.A.; Luther, S.L.; Gower, W.R., Jr. Elimination of up to $80 \%$ of human pancreatic adenocarcinomas in athymic mice by cardiac hormones. In Vivo 2007, 21, 445-452. 
41. Vesely, D.L.; Vesely, B.A.; Eichelbaum, E.J.; Sun, Y.; Alli, A.A.; Gower, W.R., Jr. Four cardiac hormones eliminate up to two-thirds of human breast cancers in athymic mice. In Vivo 2007, 21, 973-978.

42. Eichelbaum, E.J.; Sun, Y.; Alli, A.A.; Gower, W.R., Jr.; Vesely, D.L. Cardiac hormones and urodilatin eliminate up to $86 \%$ of human small-cell lung carcinomas in mice. Eur. J. Clin. Invest. 2008, 38, 562-570.

43. Crews, C.M.; Alessandrini, A.; Erikson, R.L. The primary structure of MEK, a protein kinase that phosphorylates the ERK gene product. Science 1992, 258, 478-480.

44. Wu, J.; Harrison, J.K.; Dent, P.; Lynch, K.R.; Weber, M.J.; Sturgill, T.W. Identification and characterization of a new mammalian mitogen-activated protein kinase kinase MKK-2. Mol. Cell. Biol. 1993, 13, 4539-4548.

45. Schlessinger, J. Cell signaling by receptor tyrosine kinases. Cell 2000, 103, 211-225.

46. Davis, R.J. Signal transduction by the JNK group of MAP kinases. Cell 2000, 103, 239-252.

47. Sun, Y.; Eichelbaum, E.J.; Wang H, Vesely, D.L. Insulin and epidermal growth factor activation of ERK 1/2 and DNA synthesis is inhibited by four cardiac hormones. J. Cancer Mol. 2007, 3, 113-120.

48. Ceresa, B.P.; Pessin, J.E. Insulin regulation of the Ras activation/inactivation cycle. Mol. Cell. Biochem. 1998, 182, 23-29.

49. Sun, Y.; Eichelbaum, E.J.; Lenz, A.; Wang, H.; Vesely, D.L. Four cardiac hormones inhibit insulin's mitogenic action via inhibiting Ras. Cancer Therapy 2009, 7, 367-372.

50. Kamada, T.; Feramisco, J.R. Epidermal growth factor stimulates guanine nucleotide-binding activity and phosphorylation of $n s$ oncogene proteins. Nature 1984, 310, 147-150.

51. Satoh, T.; Endo, M.; Nakaruku, M.; Akiyana, T.; Yamamoto, T.; Kazio, Y. Accumulation of p21 ras GTP in response to stimulation with epidermal growth factor and oncogene products with tyrosine activity. Proc. Natl. Acad. Sci. USA 1990, 87, 7926-7929.

52. Qui, M.S.; Green, S.H. NGF and BGF rapidly activate p21 ras in PC12 cells by distinct, convergent pathways involving tyrosine phosphorylation. Neuron 1991, 7, 937-946.

53. Medema, R.H.; DeVries-Smith, A.M.M.; Van der Zon, G.C.M.; Maasen, J.A.; Bos, J.L. Ras activation by insulin and epidermal growth factor through enhanced exchange of guanine nucleotides on $\mathrm{p}^{21}$ ras. Mol. Cell. Biol. 1993, 13, 155-162.

54. Sun, Y.; Eichelbaum, E.J.; Lenz, A.; Wang, H.; Vesely, D.L. Epidermal growth factor's activation of Ras is inhibited by four cardiac hormones. Eur. J. Clin. Invest. 2010, 40, 408-413.

55. Sun, Y.; Eichelbaum, E.J.; Wang, H.; Vesely, D.L. Vessel dilator and kaliuretic peptide activate ERK 1/2 kinases in fibroblasts. Horm. Metab. Res. 2009, 41, 197-201.

56. Skelton, W.P. IV; Pi, G.; Lenz, A.; Sun, Y.; Vesely, D.L. Cardiac hormones inhibit proliferation of pancreatic cancer but not normal cells. Eur. J. Clin. Invest. 2010, 40, 706-712.

57. Saba, S.R.; Garces, A.H.; Clark, L.C.; Gower, W.R., Jr.; Vesely, D.L. Immunocytochemical localization of atrial natriuretic peptide, vessel dilator, long acting natriuretic peptide, and kaliuretic peptide in human pancreatic adenocarcinomas. J. Histochem. Cytochem. 2005, 53, 989-995. 
58. Saba, S.R.; Vesely, D.L. Cardiac natriuretic peptides: Hormones with anticancer effects that localize to nucleus, cytoplasm, endothelium and fibroblasts of human cancers. Histol. Histopathol. 2006, 21, 775-783.

59. Waldman, S.A.; Rapoport, R.M.; Murad, F.J. Atrial natriuretic factor selectively activates membranous guanylate cyclase and elevates cyclic GMP in rat tissues. J. Biol. Chem. 1984, 259, 14332-14334.

60. Vesely, D.L. Signal transduction: Activation of guanylate cyclase-cyclic guanosine-3'-5' monophosphate system by hormones and free radicals. Am. J. Med. Sci. 1997, 314, 311-323.

(C) 2011 by the author; licensee MDPI, Basel, Switzerland. This article is an open access article distributed under the terms and conditions of the Creative Commons Attribution license (http://creativecommons.org/licenses/by/3.0/). 